\title{
ROME OUTSKIRTS, MULTIDISCIPLINARY SURVEY ON THE TRANSFORMATION OF SETTLEMENT MODELS
}

\section{PERIFERIAS DE ROMA, ENCUESTA MULTIDISCIPLINAR SOBRE LA TRANSFORMACIÓN DE LOS MODELOS DE ASENTAMIENTO}

\author{
ESTANQUEIRO, Rossana \\ Universidade NOVA de Lisboa \\ Assistant Professor \\ Av. de Berna, 26-C, 1069-061 Lisbon, Portugal \\ E-mail: rossana.estanqueiro@fcsh.unl.pt \\ Telephone: +351217908300 \\ CERASOLI, Mario \\ Roma Tre University \\ Department de Architecture \\ Associated Professor \\ Via Madonna dei Monti, 40. Rome, 00184, Italy \\ E-mail: mario.cerasoli@uniroma3.it \\ Telephone: +3906 57339687
}

Faculdade de Ciências Sociais e Humanas - NOVA FCSH, Department of Geography and Regional Planning \& Interdisciplinary Centre of Social Sciences CICS.NOVA - Faculdade de Ciências Sociais e Humanas - Universidade NOVA de Lisboa (CICS.NOVA.FCSH/UNL)

Palabras Clave: periferias, modelos de asentamientos, usos del suelo, análisis territorial, regeneración urbana.

Key words: outskirt, settlement models, land uses, territorial analysis, urban regeneration

\section{Resumen}

El fenómeno de las periferias es moderno, nació durante el siglo XIX.

Sin embargo, las definiciones tradicionales no son adecuadas para describir hoy las dinámicas complejas que involucran las grandes (y menos grandes) áreas urbanas. Por lo tanto, para hablar de la periferia es necesario revisar el significado de esta palabra e investigar las periferias urbanas contemporáneas desde diferentes perspectivas.

El estudio de los fenómenos territoriales ha sido durante mucho tiempo la prerrogativa de varias disciplinas: planificación urbana, geografía, sociología, antropología, economía, etc., son unas de las que han contribuido a enriquecer la información patrimonial sobre la ciudad y el territorio. Sobre todo, en cuanto al fenómeno de la sub-urbanización, en su base hay un claro componente cultural. El desafío que surge hoy es el de la integración entre las plataformas de datos y el intercambio. El objetivo es crear una base de datos de información permanente capaz de respaldar las elecciones de políticas y las estrategias de intervención.

Este estudio integra el enfoque de Estudios Urbanos con el de Geografía Urbana, superponiendo técnicas para leer fenómenos urbanos basados en herramientas geográficas. 
La escena romana es un rico contenedor de periferias, diferentes y desiguales, a menudo la escena de una degradación generalizada. Surgen, en la mayoría de los casos, desde el final de la Segunda Guerra Mundial y siguen creciendo hasta hoy, solo en parte siguiendo el diseño general de los planes urbanos. En Roma, las incomodidades de los nuevos barrios periféricos, principalmente diseñadas por el Plan del 1965 consisten en dificultades de movilidad y congestión del tráfico, falta de homogeneidad de distribución y escasez de servicios públicos y una dilatación general de las distancias y de los desplazamientos. El resultado hodierno es un mosaico con muchas piezas faltantes, fragmentos urbanos que producen fragmentación espacial y donde solo casos esporádicos de movilización espontánea por parte de grupos de ciudadanos han corregido la situación de hecho, rediseñando parcialmente las periferias en cuestión.

La expansión de Roma hacia el mar atravesó el siglo pasado. Esta área, durante las décadas posteriores al final de la Segunda Guerra Mundial, se ha convertido en una inmensa periferia que ha alcanzado a más de 120,000 habitantes en un área cinco veces más grande que la ciudad cercana de Ostia Lido (que, sin embargo, tiene menos de 100,000 habitantes) y una densidad de población que no supera los 25 habitantes por hectárea. Es una periferia heterogénea, predominantemente ilegal, que une la ausencia sustancial de espacios de relaciones públicas y de lugares centrales, al carácter provisional que acentúa su carácter periférico.

Es una periferia heterogénea, predominantemente ilegal, que une la ausencia sustancial de espacios públicos de relaciones, de lugares centrales, a la naturaleza provisional que acentúa su carácter periférico. En esta área, el proceso de asentamiento, después de la Segunda Guerra Mundial, comienza debido a las necesidades básicas: vivir, trabajar, etc. Sin embargo, entre los años Cincuenta y Sesenta del siglo XX comenzó a cambiar sus caracteres hacia el modelo norteamericano del suburbio. Durante treinta años se han transformado los conceptos de vida, de ciudad y de periferia. Pero este fenómeno está acompañado por un deterioro sensible de la calidad de vida y, en consecuencia, del medio ambiente. El análisis del uso del suelo ha confirmado este cambio, devolviendo un modelo de asentamiento periurbano / suburbano con densidad baja o muy baja, donde un número muy bajo de habitantes se opone a un consumo de tierra significativo.

Por lo tanto, intervenir en la periferia implica una opinión sobre la periferia que es sustancialmente diferente del sentimiento de quienes viven allí. Para ellos, este modelo de ciudad no es necesariamente negativo, sino que tiene una serie de problemas urbanísticos relacionados con la movilidad, los servicios públicos, la seguridad urbana, etc.

El ensayo indicará las diferentes opciones para la regeneración urbana de los suburbios contemporáneos. Desde la Grilla Teórica (Vittorini, 1985; Cerasoli, 2010), un instrumento de rehabilitación de las periferias finalizados a la reorganización de la estructura espacial, cuyos elementos son la calidad del espacio público de relación, la permeabilidad de la estructura urbana y la complejidad de los usos. Hasta las consideraciones que surgen de las enseñanzas recientes de Serge Latouche, teórico de la economía del decrecimiento, de Zigmund Bauman, quien introdujo el concepto de sociedad líquida, hasta llegar a la Encíclica Laudato Si' de Papa Francisco, que es un tratado de política territorial sostenible.

Citación: ESTANQUEIRO, R. y CERASOLI, M. Rome outskirts, Multidisciplinary survey on the transformation of settlement models. En: Libro de proceedings, CTV 2018. XII Congreso Internacional Ciudad y Territorio Virtual. Ciudades y Territorios Inteligentes. Mendoza, 5-7 septiembre 2018. Barcelona: CPSV, 2018, p. 97-114. 


\section{Abstract}

The outskirt phenomenon is modern; it was born during the nineteenth century.

The traditional definitions, however, are unsuitable to describe today the complex dynamics that involve large (and less large) urban areas. Therefore, to speak about outskirt it is necessary to review the meaning of this word and investigate the contemporary urban peripheries from different perspectives.

The study of territorial phenomena has long been the prerogative of various disciplines: urban planning, geography, sociology, anthropology, economics, etc. are among those that have contributed to enriching the heritage information on city and territory. Above all, as regards the phenomenon of suburbanization, at their base there is a clear cultural component. The challenge that arises today is that of integration between data and sharing platforms. The goal is to build a permanent information baggage able to support policy choices and intervention strategies. This study integrates the approach of Urban Studies with that of Urban Geography, superimposing techniques for reading urban phenomena based on geographical tools.

The Roman scene is a rich box of outskirts, different and uneven, often the scene of a widespread degradation. They arise, in most cases, since the end of the World War II and growing until today, only in part following the overall design of urban plans. In Rome, the discomforts of the new peripheral neighbourhoods, principally designed by the 1965 Urban Plan consist in difficulties of mobility and traffic congestion, distribution inhomogeneity and scarcity of public services and an overall dilation of distances and displacements. Today's result is a mosaic with many missing pieces, urban fragments that produce spatial fragmentation and where only sporadic cases of spontaneous mobilization by groups of citizens have correct the factual situation, partially redeveloping the outskirts concerned.

The expansion of Rome towards the sea went through the last century. This area over the decades following the end of World War II has become an immense outskirt that has reached more than 120,000 inhabitants in an area five times larger than the nearest city of Ostia Lido (which, however, has just under 100,000 inhabitants) and a population density that does not exceed 25 inhabitants per hectare. It is a heterogeneous outskirt, prevalently illegal, that unites the substantial absence of public space of relations, of central places, to the provisional nature that accentuates its peripheral character. In this area the settlement process, after the Second World War, begins due to basic needs- living, working, etc. -, however between the Fifties and Sixties of twentieth century it began to change its characters towards the North American model of the Suburb. During thirty years the concepts of living, of city and of outskirt have been transformed. But this phenomenon is accompanied by a sensitive decay of the quality of life and, consequently, of the environment.

The land use analysis has confirmed this change, returning a peri-urban / suburban settlement model with low or very low density, where a very low number of inhabitants are opposed to a significant land consumption. Therefore, to intervene in the outskirt implies an opinion about the outskirts that is substantially different from the feeling of those who live there. For them, this model of city is not necessarily negative but has a series of urban planning problems related to mobility, the public services, urban security, etc.

Citación: ESTANQUEIRO, R. y CERASOLI, M. Rome outskirts, Multidisciplinary survey on the transformation of settlement models. En: Libro de proceedings, CTV 2018. XII Congreso Internacional Ciudad y Territorio Virtual. Ciudades y Territorios Inteligentes. Mendoza, 5-7 septiembre 2018. Barcelona: CPSV, 2018, p. 97-114. 
The essay will indicate the different options for urban regeneration of contemporary suburbs. It will range from the Theoretical grid (Vittorini, 1988; Cerasoli, 2008), an instrument of rehabilitation of the peripheries finalized to the reorganization of the spatial structure, whose elements are the quality of the public space of relation, the permeability of the urban structure and the complexity of the uses. Up to considerations that arise from the recent teachings of Serge Latouche, theoretician of the economy of degrowth, of Zigmund Bauman, who introduced the concept of liquid society, until arriving at the Encyclical Laudato Si' of Pope Francis, that is a treaty of sustainable territorial policy.

\section{Evolution of the concept of outskirt.}

The phenomenon of the outskirts is modern, born by the Industrial Revolution and is usually accompanied by the demolition of the old urban walls, during the 19th century. Dictionaries define it as the set of neighbourhoods arranged to the outer margins of an urban nucleus but also as the most external and most marginal zones, as opposed to the centre, a space or a territory. However, these definitions have become less and less adequate to describe the complex dynamics that involve large (and small) urban areas. In fact, today there are peripheries in the interior of cities - areas embedded in urban development that have lost their original functions or that have been affected by abandonment phenomena - and, on the contrary, outer suburbs characterized by the dispersion, which do not have those characteristics - of degradation and marginalization - common to many peripheries.

For this reason, to speak of outskirts it is necessary to review the very meaning of the word outskirts and to investigate the contemporary peripheries from a different perspective. Since the end of World War II, the city experienced profound transformation processes both in the morphological rules of settlements and, especially, in the living models. Transformation that has transversally affected the whole world, which, with the appropriate distinctions, has begun a (one-way) journey towards globalization.

In Italy, countryside and smaller centres have gradually emptied, while large cities have begun to grow, more or less able to accommodate the internal migratory waves. Effect of these settlement dynamics, starting in the late Sixties, processes of physical degradation and consequently social begin to manifest themselves in the cities. Processes that initially affect the historical centres of the cities (which, due their nature, consist of a prevalence of poor buildings, which do not guarantee - apparently - the modern requirements of living comfort and which are progressively abandoned). And the new districts of social housing (almost always located in the suburbs, thus producing the popular suburbs), characterized by low quality buildings, often without services, sometimes born as arrogant architectural experiments, where the less well-todo classes are you have been segregated. Yet, in all parts of the world, people - then like today - pursued the same dream: a decent home and a job! Since then, the distribution of work and wealth has been increasingly diversifying. With it, the settlement myths have begun to transform, chasing all the American myth that is imposed after the end of the Second World War.

The process of suburbanization is therefore an invention of the contemporary city. It then repeats exactly what happened in the aftermath of the Industrial Revolution, when the newly born bourgeoisie went to settle in the new neighbourhoods outside the existing (historical) city. In recent decades, in fact, for an emulative process, the middle class leaves the historic centre to go to live in a low-density suburb, characterized by single-family houses with gardens (or, in urban contexts of more recent urban development, in exclusive buildings such as towers). All of

Citación: ESTANQUEIRO, R. y CERASOLI, M. Rome outskirts, Multidisciplinary survey on the transformation of settlement models. En: Libro de proceedings, CTV 2018. XII Congreso Internacional Ciudad y Territorio Virtual. Ciudades y Territorios Inteligentes. Mendoza, 5-7 septiembre 2018. Barcelona: CPSV, 2018, p. 97-114. 
this is confirmed - even on a global level - by the fact that almost $55 \%$ of the world population is concentrated in urban areas. Nevertheless, more than a third of these lives in low-density suburbs and the (unsustainable) trend is towards the growth of these percentages.

We went beyond the outskirt.

\section{Multidisciplinary approach for the study of settlement transformations}

The study of territorial phenomena has long been the prerogative of various disciplines, beyond urban planning, Geography, Sociology, Anthropology, Economics, Geology are among those that have contributed to enriching the information heritage of the city and the territory.

The challenge that arises today is that of integration between data and sharing platforms. The goal is to build a permanent information baggage able to support policy choices and intervention strategies. Above all as regards the phenomenon of suburbanization, at the base of which there is a clear cultural component.

In particular, this study integrates the approach of Urban Studies with that of Urban Geography, superimposing techniques for reading urban phenomena based on advanced tools and technologies.

\section{Rome and its outskirts. Evolution and characters}

The Roman scene is a rich container of suburbs, different and uneven, often the scene of a widespread degradation, which arise, in most cases, from the end of the Second World War and whose growth reaches until today, following only in part of the overall design of urban plans.

In Rome, forty years after the construction of the new suburban neighbourhoods envisaged by the 1965 Urban Plan, in these parts of the city, now consolidated, the discomforts translate into difficulties of mobility and traffic congestion, inhomogeneity in the distribution of public services and in an overall expansion of distances. What results today is a mosaic with many missing pieces, urban fragments that in turn produce fragmentation and where only sporadic cases of spontaneous mobilization by groups of citizens have solved the fate, partially redeveloping the areas concerned.

\subsection{Birth and expansion of the Roman outskirts}

Rome, capital of the Italian State since 1871, is the European capital with perhaps the most unusual urban history. Founded by the ancient Romans, after the fall of the Imperium, it lived a long phase of decline related to the barbarian invasions from which it recovered only after the birth of the State of the Church, in the year 728. Under the Church, the urban history of Rome is evidently linked to the policies of the Popes, which, on the one hand, characterize its architectural splendour, but on the other, they determine its progressive territorial (and political) isolation.

Some data is interesting. At the height of its splendour, around the third century, Rome, then Capital of the Roman Empire, had around 1,500,000 inhabitants, mostly residents within the ancient walls. At the time of joining the Kingdom of Italy, in 1870, Rome had a little more than

Citación: ESTANQUEIRO, R. y CERASOLI, M. Rome outskirts, Multidisciplinary survey on the transformation of settlement models. En: Libro de proceedings, CTV 2018. XII Congreso Internacional Ciudad y Territorio Virtual. Ciudades y Territorios Inteligentes. Mendoza, 5-7 septiembre 2018. Barcelona: CPSV, 2018, p. 97-114. 
150,000 inhabitants, mainly concentrated in the north-western part of the walled city, today its historic centre (where today almost 144,000 inhabitants live).

From 1870, Rome is endowed with 6 urban plans, with which initially attempts to design the modern city, capital of Italy. With the two expansion plans of 1873 and 1883, the issue of the construction of the Capital of the new unitary State is addressed and the headquarters of the government, the parliament, the ministries and everything necessary for the proper functioning of the state machine are designed. At the same time the new neighbourhoods to welcome workers, employees and leaders of the new State are designed.

Figure 1. Plan de 1873 (Ing. A. Viviani)

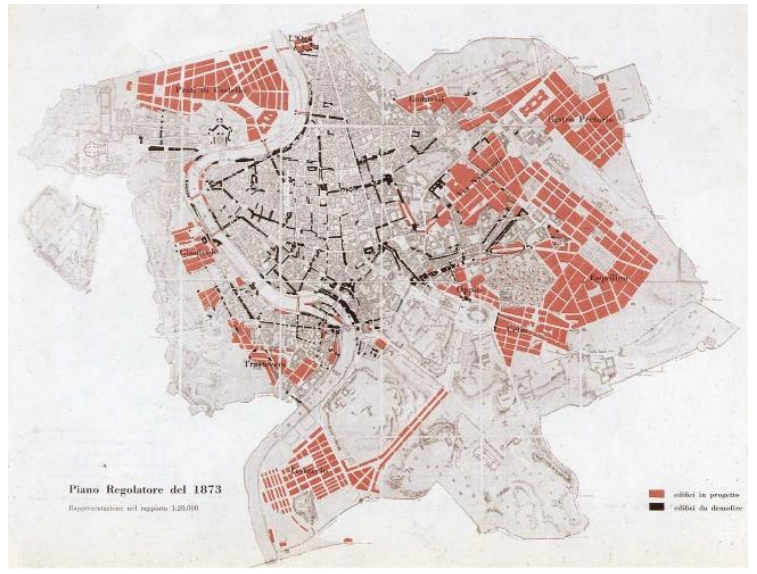

Source: Comune di Roma

With the 1909 Plan, for the first time the expansion of the city totally, outside the ancient Roman Walls, is planned. This Plan introduces a technical device for the control of the building, within the framework of a complex design of the city that seeks to prevent the growth as like a wildfire. It is the first time that an urban plan tries to regulate the real estate activity and the urban rent. However, with scarce results.

Figure 2. Plan de 1909 (Ing. E. Sanjust di Teulada)

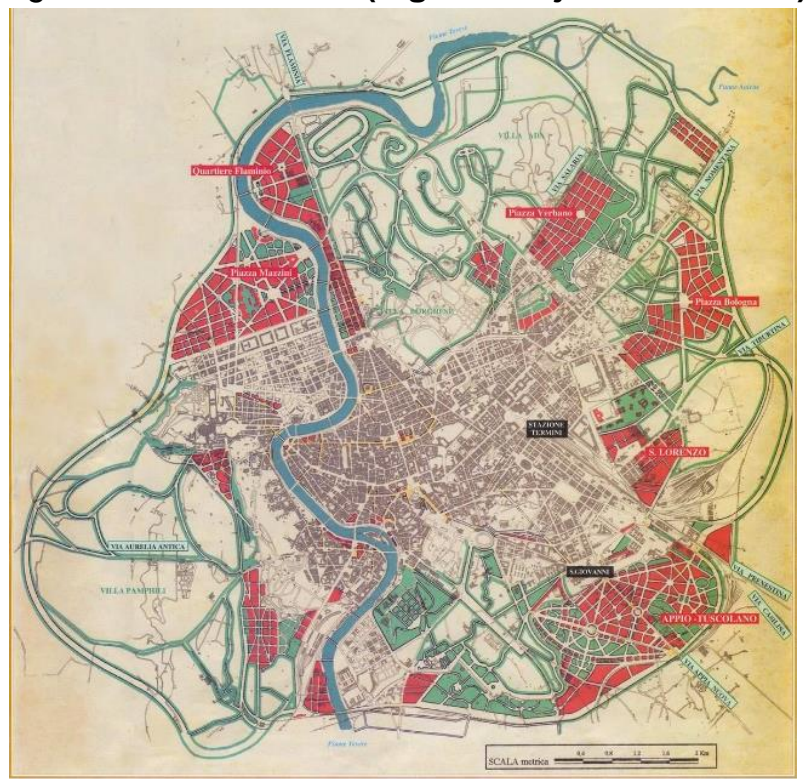

Source: Comune di Roma

Citación: ESTANQUEIRO, R. y CERASOLI, M. Rome outskirts, Multidisciplinary survey on the transformation of settlement models. En: Libro de proceedings, CTV 2018. XII Congreso Internacional Ciudad y Territorio Virtual. Ciudades y Territorios Inteligentes. Mendoza, 5-7 septiembre 2018. Barcelona: CPSV, 2018, p. 97-114. 
The Plan of 1931 (Arch. Marcello Piacentini), drawn in the middle of the Fascist Twenty, extends the limits of the city almost $25 \%$. However, with its contradictions fruit of strong political, economic and cultural commitments (Rossi, 1991) lays the foundations of the modern outskirts of Rome. This Plan ignores a whole series of spontaneous settlements, born above all along the comfort roads, which have contributed to the development of another city characterized by degradation and poverty.

Figure 3. Plan de 1931 (Arch. M. Piacentini)

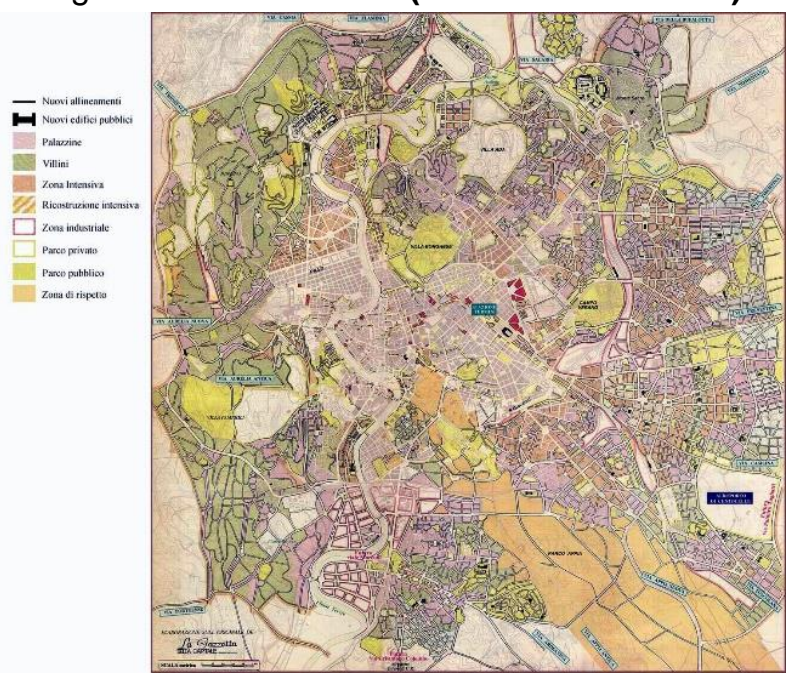

Source: Comune di Roma

The two most recent plans of contemporary Rome, the one of 1962 and the current one of 2003-2008, have to face first of all the housing emergency of the years immediately after the economic boom (1958-1962) and then with the problem of the degradation of the outskirts.

The 1962 Plan is born of a hard confrontation between the different political forces in the government and the opposition in the municipal administration of Rome. The debate lasts 9 years and yet does not end with the final approval of the Plan in 1965 but after the approval of the Law of Social Housing (no. 167 of 1962). This implies the immediate drafting of a general variant that, with its approval in 1971, definitively concludes the drafting process of the 1965 Plan, adapting it to the new law.

Figure 4. Plan de 1965 (Arch. P.M. Lugli)

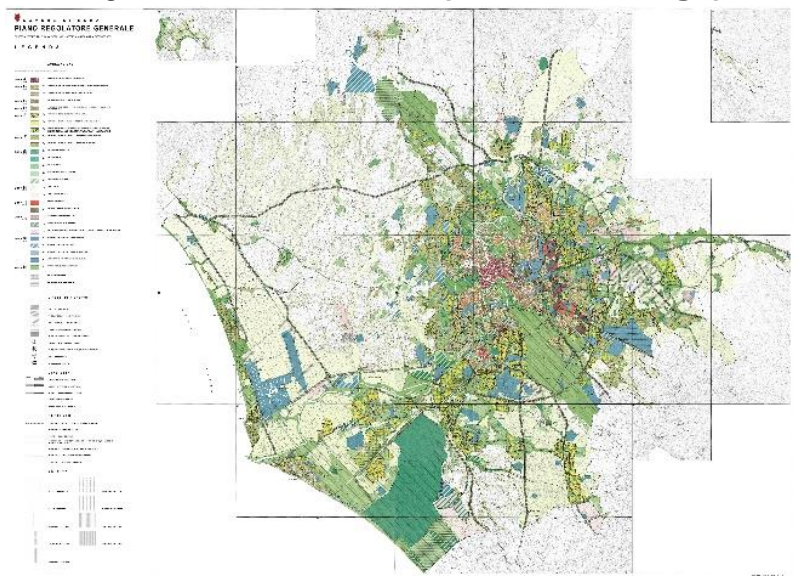

Citación: ESTANQUEIRO, R. y CERASOLI, M. Rome outskirts, Multidisciplinary survey on the transformation of settlement models. En: Libro de proceedings, CTV 2018. XII Congreso Internacional Ciudad y Territorio Virtual. Ciudades y Territorios Inteligentes. Mendoza, 5-7 septiembre 2018. Barcelona: CPSV, 2018, p. 97-114. 
The 1962 Plan is the first urban plan designed in accordance with the new National Urbanistic Law, n. 1,150 of 1942 . The main novelty of this law is that the municipal plan must take into account the totality of the municipal territory and not only the part of the existing city and the new planned urban expansions. This Plan is characterized by some key projects of great interest and quality such as the Eastern Directional System, the Equipped Axis and the Via Appia Antigua Park: proposals that go back to the first draft of the Plan, designed by a team of urban planners, coordinated by Luigi Piccinato. However, during the difficult period of completion and after approval, the Plan also encourages the increase in construction forecasts. Increase justified by fairly simplistic demographic estimates, which probably had to support very strong property interests. Then, for Rome, which has then almost 2,200,000 inhabitants, the Plan foresees a substantial duplication of the city, however, framed in a city already strongly compromised by legal and illegal growth located outside the perimeter of the previous Plan of 1931.

The scenario in which the Plan of 1965 is going to be inserted is that of a second housing emergency, which can be interpreted perhaps as the reverse of that medal that was the (ephemeral) Italian economic boom of the late Fifty. Emergency due to the great real estate speculation that had been registered immediately after the Second World War and that in one way or another had excluded from the residential real estate circuit a multitude of lower income people who usually came to Rome in search of fortune. That is why, unfortunately, the execution of the key projects of the Plan is abandoned. Consequently, a strong demand for housing arises and the Municipality ty of Rome launches two Programs for Social Housing, in 1964 and in 1983, which provided houses respectively for 700,000 and 190,000 inhabitants. Less than half of the demographic forecasts of the PRG 1962 but evidently insufficient. Fact that has favoured the growth of that supplementary, illegal city, made by towns and small built nucleus that already in 1971 has 600,000 inhabitants (Rossi, 1993).

Figure 5. Plan de 2008 (Arch. G. Campos Venuti)

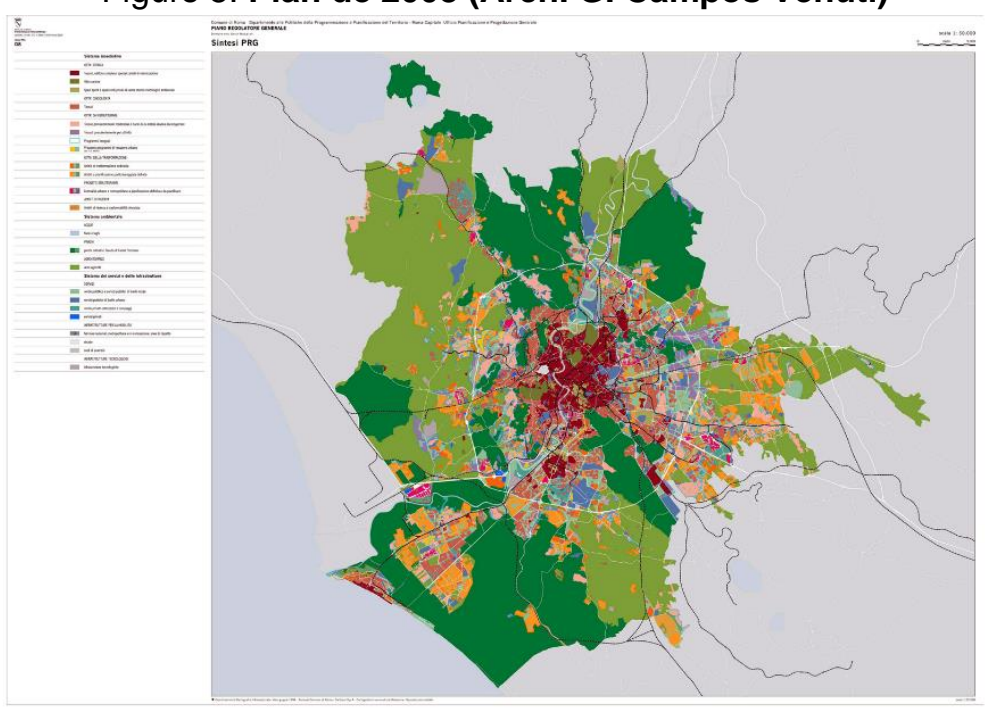

Source: Comune di Roma

It is necessary to arrive in the middle of the Nineties so that the Plan of 1962 is revised and the design of a new urbanistic instrument is put into operation, which finally is approved in March of 2008. The 2008 Plan sets out five strategic lines of great interest: the metropolitan dimension, the principle of sustainability, the mobility system, the primacy of the outskirts and the disadvantaged city, the role of history for a transformation of quality (Ricci, 2014). 
However, at the same time it surrenders to the strong pressures of real estate operators, foreseeing a new city, for the most part low and very low density, for another 500,000 inhabitants - when Rome, since 1971, is in a substantial demographic stasis (remaining around 2,800,000 inhabitants).

The peripheries of Rome today still constitute more than a third of the existing city.

Figure 6. Rome south-west outskirts

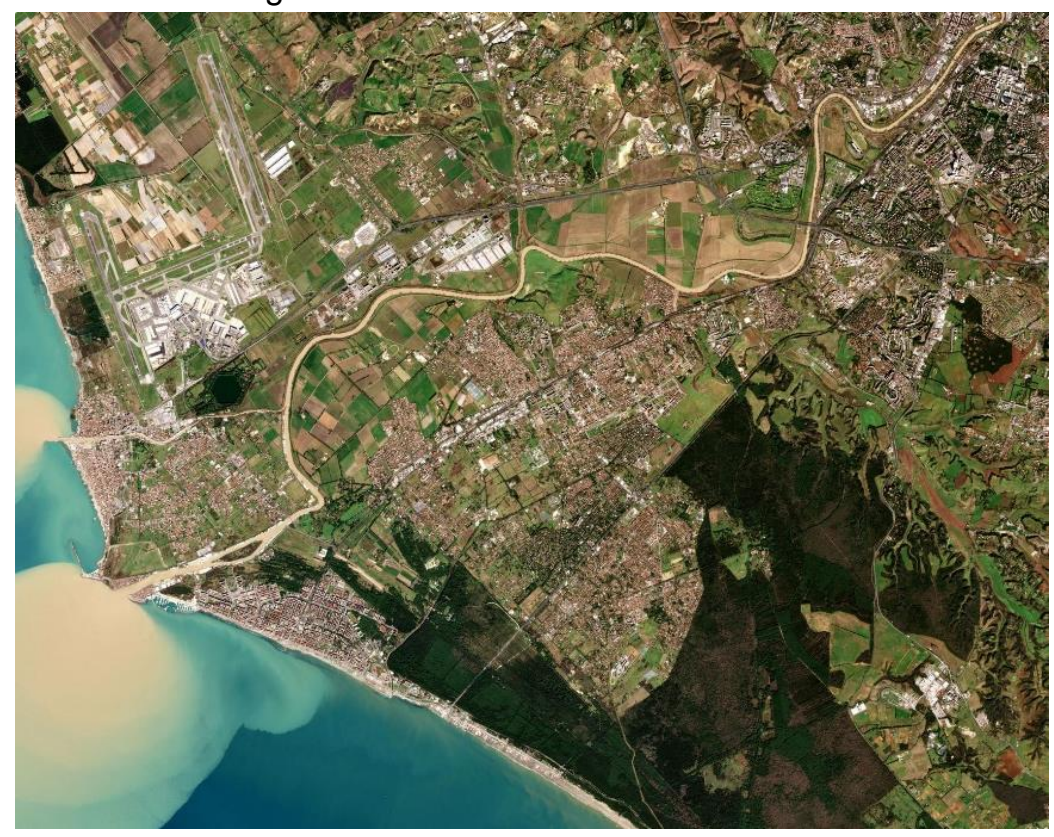

Source: ESA - ESRIN, 2018

\section{The Rome outskirt towards the sea}

The Rome south-west peripheral settlements are developed along two roadways, via Ostiense and via Cristoforo Colombo. The first goes back to the ancient Romans, who had built it to connect the port of Ostia (Antigua) - the coastline then - to the city of Rome. The second one, between 2 and $4 \mathrm{~km}$ from the first one, dates back to the late Thirties, when the works related to the Universal Exposition of 1942 began to be carried out, which nevertheless never took place and which subsequently became the district of the EUR. It is a outskirts that can be considered as a substantially unique case: it has well-defined limits, it is located between the natural confines of the Tiber River (Tevere) to the north, the Pine forest of Castel Fusano to the west and the Presidential Farm of Castel Porziano to the southeast. These are natural limits that are difficult to cross. An outskirt that has limits constitutes in itself a conceptual paradox, a contradiction in terms. However, the one we are talking about is a outskirts in all aspects, although in continuous evolution.

This urbanized satellite, which includes Ostia Antica, Acilia, Dragona, Casal Palocco, Infernetto, has grown exponentially in the last 60 years and has reached more than 140,000 inhabitants in an area seven times larger than the area where it is currently located. develops the neighbourhood-city of Ostia Lido - which has a little less than 80,000 inhabitants -e with a housing density that barely exceeds 21 inhabitants per hectare $(2,100$ inhabitants / km2). A population that could be that of an average city as Bergamo with 120,000 inhabitants, for example, where nevertheless there are hospitals, universities and other services such as

Citación: ESTANQUEIRO, R. y CERASOLI, M. Rome outskirts, Multidisciplinary survey on the transformation of settlement models. En: Libro de proceedings, CTV 2018. XII Congreso Internacional Ciudad y Territorio Virtual. Ciudades y Territorios Inteligentes. Mendoza, 5-7 septiembre 2018. Barcelona: CPSV, 2018, p. 97-114. 
qualified public infrastructure. Instead, in these outskirts there is practically none of the services that characterize and qualify a city. Only those of basic need specialized to satisfy the demands of those who work in another part of the city and return home only to sleep.

In this vast urbanized area, two types of settlements coexist: those spontaneous and those planned, the first born on the thrust of different waves of emergencies housing, the latter almost all in implementation of the PRG of 1965. This area is heterogeneous and is characterized by the rarefaction of public space and central places and because it is still incomplete: streets frequently without sidewalks and ending in nothing or interrupting; shortage of green spaces and public services; abandoned and degraded areas. All elements that can easily transform it into scenarios for illegal activities (robbery, drugs and prostitution). More than a part of the city, it looks like a jam of buildings, where one goes only to sleep.

If this settlement process, after the Second World War, begins with necessity - living, working at a time when the public administration is unable to deal with the housing problem, over the years it changes its characters towards the model of the Suburbia (composed of individual houses with gardens, far from the city centre). People have accustomed themselves to living in these heterogeneous suburbs that unite the substantial absence of public spaces in relation to that provisional nature which accentuates its suburban character. Moreover, he begins to no longer perceive the problem of absence of city as a primary problem. In simple terms, in the space of thirty years the concept of living, of city, of suburbs has been transformed. Nevertheless, this phenomenon is accompanied by a sensitive decay of the quality of life and, consequently, of the environment.

\subsection{Historical evolution}

The expansion of Rome towards the Sea is generated by a design that has completely crossed the 20th century - despite the attempts to orient the development of the urban expansion to the East that took place in the following decades. This expansion originates from the neighbourhoods of economic and popular housing made since the seventies around the district of the EUR, bulwark of the fascist utopia, reaching the coast, in Ostia.

The origin of this outskirts dates back to the immediate post-war, although the first nucleus was part of a strategy for the expansion of Rome to the sea that took its first steps in the early twentieth century and then was taken up by Fascism. Already at the beginning of the twentieth century were born the residential expansion of the historic core of Ostia Antigua, with the construction of the houses of the socialist housing cooperative made by agricultural workers, and the settlement of Acilia (1939).

At the end of the fifties was born the garden district of Casalpalocco (1959), a new residential neighbourhood built along the Colombo road, which refers to the Anglo-Saxon city-garden. Casalpalocco then represented a - legitimate - real estate speculation, which obtained the approval of a Lotification Plan in an area not yet affected by any urban expansion. On the side of Casal Palocco, two years later, in 1961, the construction of the residential district of the AXA (Construction Company Agrícola Para Acciones, later transformed into Associazione Consortile Società per Azioni ACSA) began. The AXA will complete the panorama of this elite residential suburb. Recipients of these two new settlements were to be the workers (pilots, crews, technicians, employees) of the new Fiumicino Intercontinental Airport (15 km away), which opened in 1962.

Citación: ESTANQUEIRO, R. y CERASOLI, M. Rome outskirts, Multidisciplinary survey on the transformation of settlement models. En: Libro de proceedings, CTV 2018. XII Congreso Internacional Ciudad y Territorio Virtual. Ciudades y Territorios Inteligentes. Mendoza, 5-7 septiembre 2018. Barcelona: CPSV, 2018, p. 97-114. 
Figure 7. Casal Palocco district

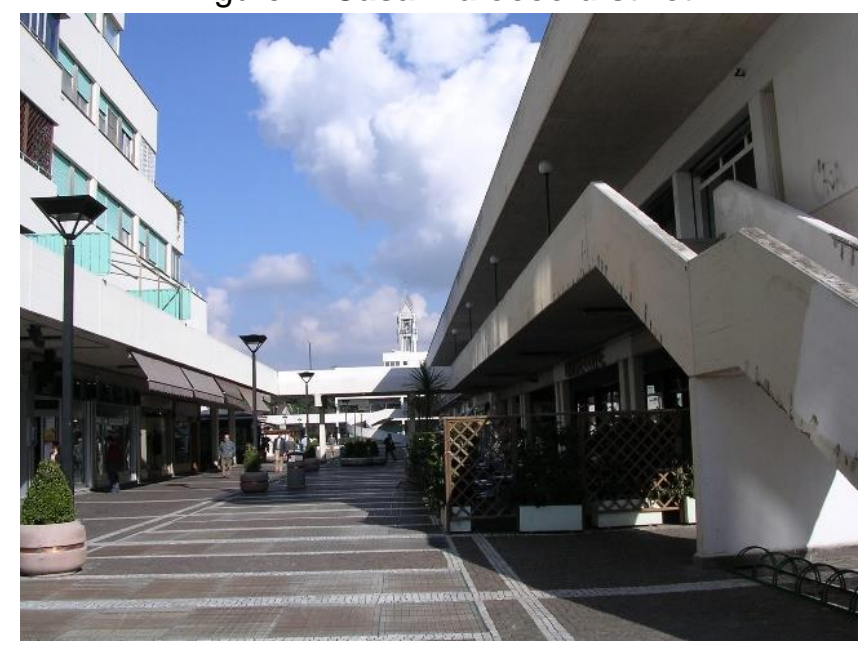

Source: Mario Cerasoli Photography

Around the old and new settlements, in these same years a phenomenon of progressive real estate erosion is taking place, giving birth to the first illegal nuclei: Dragona and Centro Giano, next to Acilia, which in turn expands. Suburbs poor far from the city, where the people who decided to come to the big city, Rome, in search of fortune at the time of economic boom of the late Fifty, was located. These people, unable to access the housing market in the existing central city, invested their savings to buy a plot of land, and usually self-built their own home. Houses often very modest, which took into account the future needs of the family and therefore often remained unfinished in view of possible extensions and elevations.

These are cases of illegal housing of first necessity.

Figure 8. Dragona district

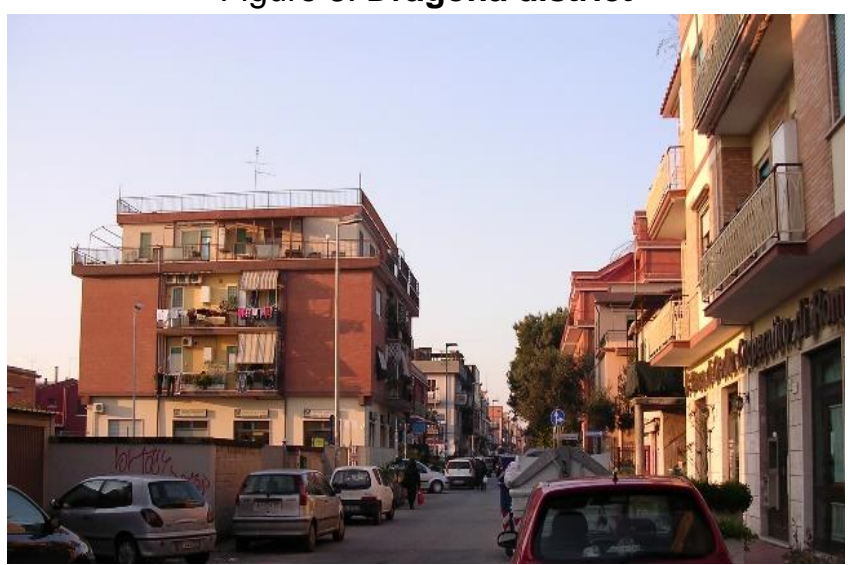

Source: Mario Cerasoli Photography

Between the two types of settlement the relationship with the infrastructures and then the mobility patterns are initially different. If the suburbs such as Casal Palocco and AXA connect directly with the highways and, therefore, base their mobility models on the use of the private car, the illegal neighbourhoods are located along the public transport lines, in this case mainly the Rome-Lido railway.

Citación: ESTANQUEIRO, R. y CERASOLI, M. Rome outskirts, Multidisciplinary survey on the transformation of settlement models. En: Libro de proceedings, CTV 2018. XII Congreso Internacional Ciudad y Territorio Virtual. Ciudades y Territorios Inteligentes. Mendoza, 5-7 septiembre 2018. Barcelona: CPSV, 2018, p. 97-114. 
As we saw previously, the Plan de 1965 tries to solve the housing problem. In particular, for this urban sector, the Plan foresees the construction of some new neighbourhoods. Among these, the Drangoncello neighbourhood, which is named after an irrigation canal that marks su limite and separates it from Dragona, was built in the Seventies. Dragoncello is a modernist neighbourhood. Its urban design is characterized by an eccentric nucleus that concentrates some collective functions and a road structure that is based on large road arteries and several lanes that surround the neighbourhood but do not meet north - for a stupid problem of altitude. It is articulated in some built cores that form large courts, with large and less large buildings, and with a single central place consisting of a supermarket and a few commerces. Large green areas cover the entire area, but are usually enclosed (resulting in a kind of green-closed). Despite the appearances, Dragoncello clearly is not (enough?) An attractive neighbourhood, joining the worst characters of the city - living narrow apartments in condominiums and real estate values not low - and the outskirts - absence of services, need to travel by car to reach any primary need (services, work, study, recreation, etc.).

Faced with this type of response by urban planning, at the beginning of the Seventies in these vast outskirts, which continues to grow, there is a progressive transformation of settlement patterns, undoubtedly linked to the massive diffusion of new cultural patterns. The implementation of abusive subdivisions changes, they are no longer related to the maximization of land exploitation, but to respond to the new demands of the population, now more varied. The consumption of the territory is produced by an urban fabric that loses the geometric and efficient characteristics of the first illegal nuclei of twenty years before and that continue growing until today, facilitated by three amnesties of the illegal constructions.

Figure 9. Illegal settlements

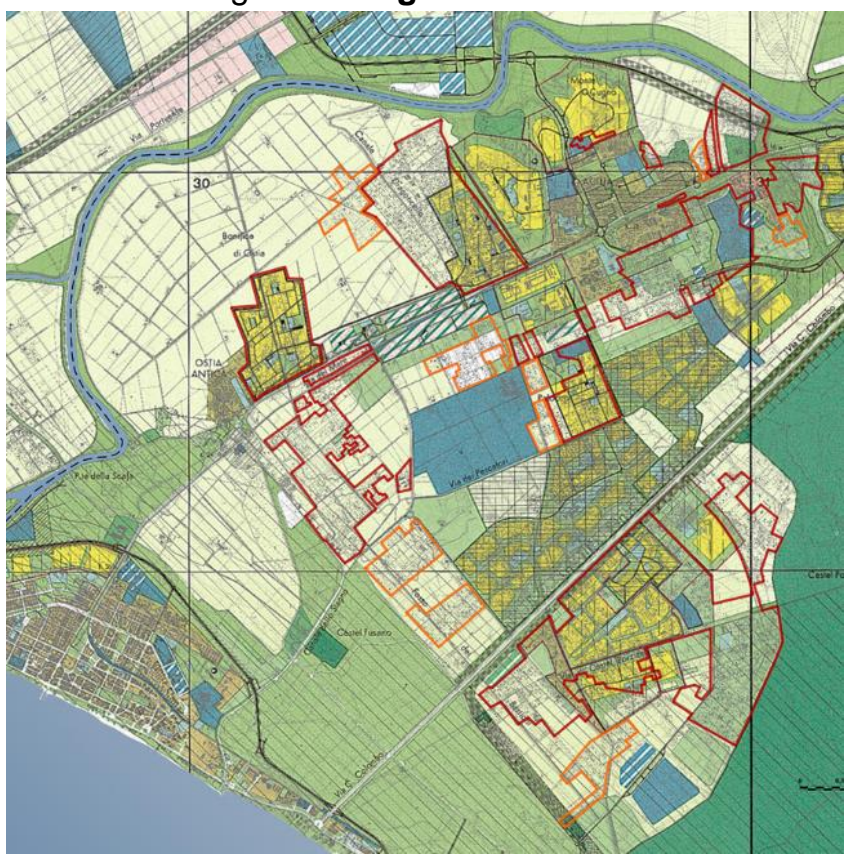

Source: Reworked by Cristina Colagiacomo (based on Plan 1965)

If this process begins with necessity - life, work - at a time when governments cannot - and sometimes do not want - to face the problem of housing, this model has not been in place for more than two decades, settlement dangerously mutates its own character. In those years, we then witness the birth and spread of the phenomenon of massive suburbanization based on

Citación: ESTANQUEIRO, R. y CERASOLI, M. Rome outskirts, Multidisciplinary survey on the transformation of settlement models. En: Libro de proceedings, CTV 2018. XII Congreso Internacional Ciudad y Territorio Virtual. Ciudades y Territorios Inteligentes. Mendoza, 5-7 septiembre 2018. Barcelona: CPSV, 2018, p. 97-114. 
luxury real estate self-promotion. The detached house with garden, far from the city centre, becomes one of the most popular options in recent years. In this context, cities began to be invaded by atmospheric pollution caused to a large extent, in a vicious circle, product of vehicular traffic, generated by those who live in the dispersed outskirts and have to arrive daily at the center of the city by private means of transport.

All the negative characters of the outskirts and the suburb have been overcome by this type of housing model, based on a general economic evaluation. In some way, it should make us reflect on the change of the concept of outskirt and city.

The distance between these outskirts and the centre of the city, the places of work and study, the services and equipment of first necessity and also the places for free time and entertainment is compensated by the forced use of the car or motorbike, thus altering the perception of limit of the settlement.

The settlement limit is no longer that which has traditionally been associated with the distances that can be walked, the recognition of the city as a place of concentration of population and commerce; but to what relates to the comfort of the car. The rest of the daily necessities are offered by some gigantic shopping centres, designed to arrive by car, satellite and, above all, Internet. The uncertain local identity of some fringes of the territory of these wide outskirts represents one of the recurring characteristics.

The outskirts should be an embryo of the city of tomorrow. However, these outskirts will never be a city.

\section{Geographical analysis and semantic structure of the land use}

The map of the study area was produced on the basis of European land use and land cover mapping for the year 2012, made available by the European Environment Agency - the European Urban Atlas. The European urban atlas, a project initiated by the European Commission in 2009, considers a set of technical specifications and criteria for extracting information on land use/land cover from the classification and interpretation of satellite images with high spatial resolution (2.5 meters).

It is therefore Pan-European information based on the application of cross-cutting methodology to the different Member States, allowing the comparative analysis of a wide range of European urban areas with more than 100 thousand inhabitants (currently counting about 309 urban areas).

The legend nomenclature integrates a hierarchical set of thematic classes, distributing up to level IV of maximum disaggregation in the case of class 1 Artificial areas (minimum cartographic unit: $0.25 \mathrm{ha}$ ). The remaining classes (class 2 Agricultural areas + semi-natural media + wetlands, class 3 Forests and class 5 Water bodies) show the lowest disaggregation (level I), considering 1 ha of minimum cartographic unit.

Citación: ESTANQUEIRO, R. y CERASOLI, M. Rome outskirts, Multidisciplinary survey on the transformation of settlement models. En: Libro de proceedings, CTV 2018. XII Congreso Internacional Ciudad y Territorio Virtual. Ciudades y Territorios Inteligentes. Mendoza, 5-7 septiembre 2018. Barcelona: CPSV, 2018, p. 97-114. 
Figure 10. South-western suburbs of Rome. Land use and land cover map.

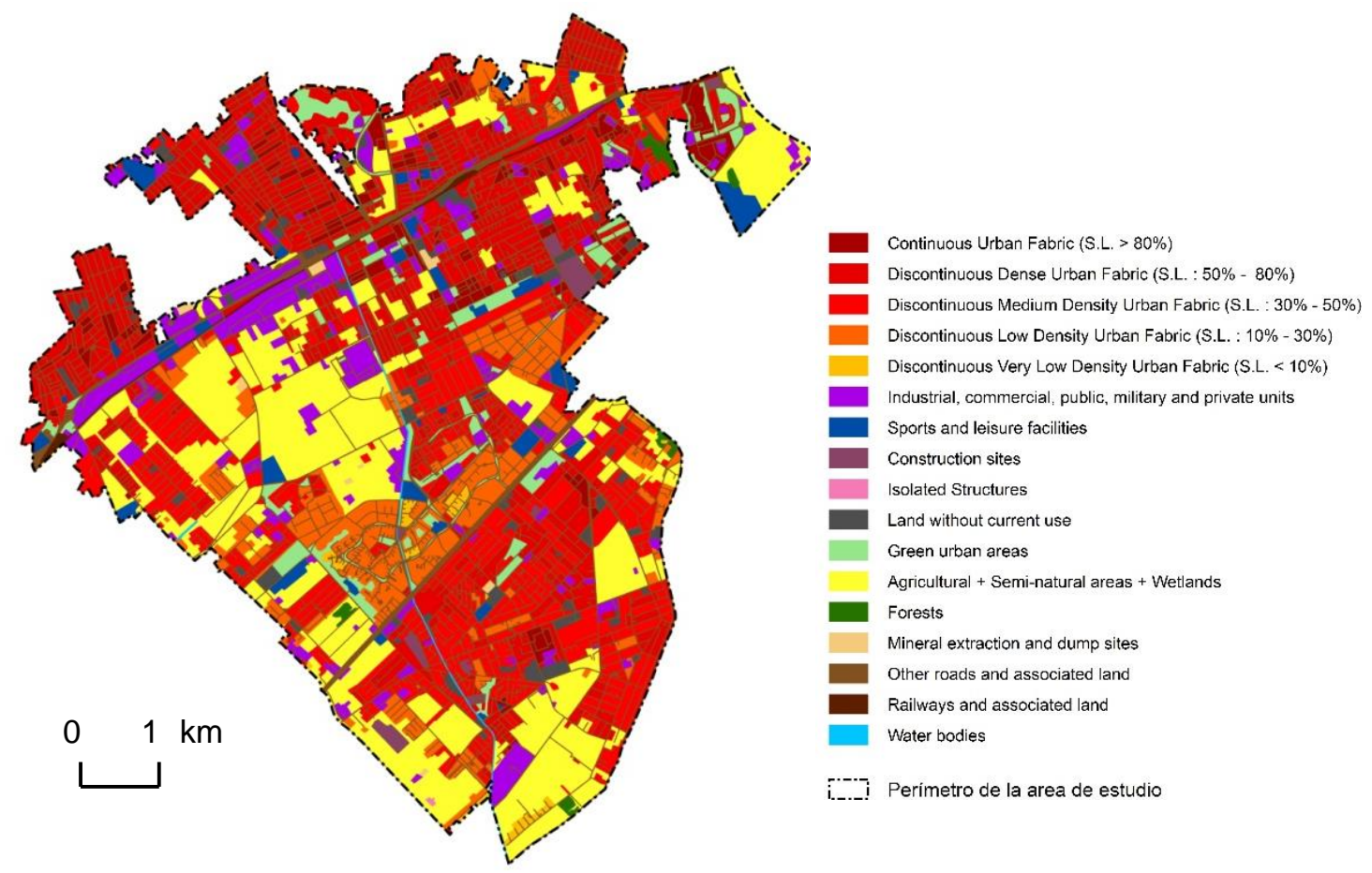

Source: European Urban Atlas (2009), reworked by Rossana Estanqueiro

From a total of twenty-six classes (from level I to level IV) of the Urban Atlas nomenclature, the study area comprises only 17 thematic classes mainly distributed by the different levels of class 1 Artificial areas. Considering the legend of the image and the descriptions of the different classes (http://www.eea.europa.eu/data-and-maps/data/urban-atlas) we can infer that they are fundamentally inspired by the following concepts: continuity or spatial discontinuity, density of impervious urban area.

The density concept is associated to the urban fabric classes, which are distinguished by the percentage of the weight of the impervious surface, not including the type of built-up area that affects the single family or multi-family (dominance of verticality versus horizontality of the builtup areas).

The concepts of continuity and spatial discontinuity are associated to the classes that are distinguished by the degree (average) percentage of impervious land area. The notion of spatial continuity refers to urban fabrics characterized by predominantly residential built-up areas and their associated spaces, occupied by a greater percentage weight of impervious surface (average more than $80 \%$ ), being represented by the class Continuous urban fabric ( $\mathrm{SL}>80 \%$ ).

On the other hand, the spatial discontinuity implies an average percentage weight of impervious surface that can vary in the interval between $10 \%$ and $80 \%$, thus distinguishing itself from the continuous urban fabric class by the fraction of land area occupied by areas not impervious and / or vegetated surfaces (gardens, parks and areas with vegetation cover without being used for agricultural or forestry purposes). In this case, we have associated four classes of discontinuous urban tissue presented in the study area

Citación: ESTANQUEIRO, R. y CERASOLI, M. Rome outskirts, Multidisciplinary survey on the transformation of settlement models. En: Libro de proceedings, CTV 2018. XII Congreso Internacional Ciudad y Territorio Virtual. Ciudades y Territorios Inteligentes. Mendoza, 5-7 septiembre 2018. Barcelona: CPSV, 2018, p. 97-114. 


\section{Perspectives (interdisciplinary) of urban regeneration}

How (and if) to intervene in the suburbs, then? It is the most sensitive issue that must be addressed, because it implies an opinion on the periphery that is substantially different from the opinion of those who live there. For them, the urban life model that the suburbs represent is not necessarily negative, except for a minimal set of inconveniences related to mobility or public services.

Then, the Theoretical Grid can come to our aid. It is a working hypothesis that was launched by the urban planner Marcello Vittorini already in the middle of the Eighties and that was later developed and better defined through research in the Department of Architecture of the University Roma Tre, where for some years a study has been initiated on the forms of the contemporary city. Its criteria come from the western urban tradition, which, reinterpreted to favor the improvement and regeneration of portions of the degraded urban periphery, converges into an urban grammar. This grammar identifies the spatial and functional criteria of urban rehabilitation, aimed at the reorganization of the spatial structure.

Key elements of the Theoretical Grid are:

- forms and boundaries of the urban fabric;

- the quality of the public space and the system of the central places;

- the complexity of urban uses and the accessibility to public services;

- $\quad$ the participatory planning and public-private concertation;

- the system of sustainable mobility and the right to the city.

The Theoretical grid is also based on a multidisciplinary approach that combines urban planning, mobility planning, architectural planning, as well as economics, sociology, anthropology and urban geography.

Figure 11. The Theorical Grid

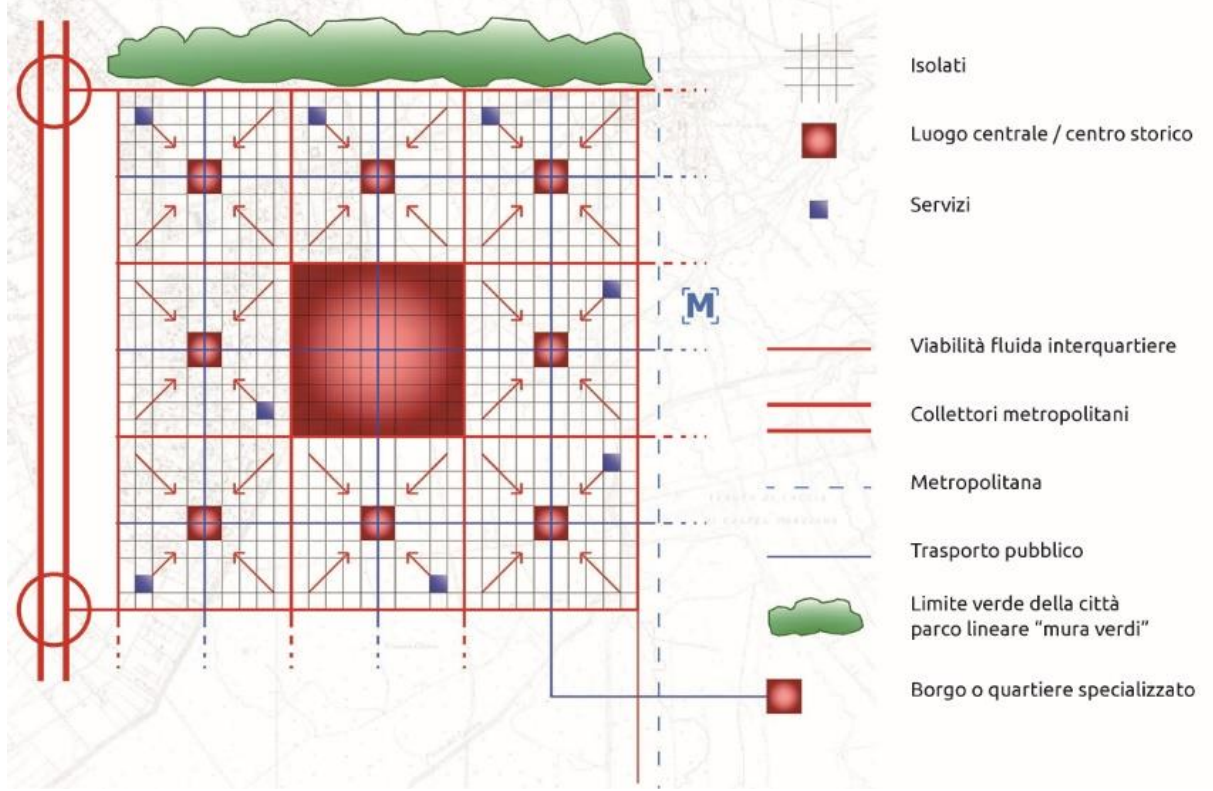

Source: Mario Cerasoli (elaborated by Michele Carpani)

Citación: ESTANQUEIRO, R. y CERASOLI, M. Rome outskirts, Multidisciplinary survey on the transformation of settlement models. En: Libro de proceedings, CTV 2018. XII Congreso Internacional Ciudad y Territorio Virtual. Ciudades y Territorios Inteligentes. Mendoza, 5-7 septiembre 2018. Barcelona: CPSV, 2018, p. 97-114. 
What application could this grammar have? In several Urban Planning and Urban Design courses of the Faculty of Architecture of the Roma Tre University, this grammar has been experienced, applying it in different areas of Rome and its surroundings.

The application has mainly focused on the redefinition of mobility combined with the identification of a central system of existing or planned centralities.

The application of the Theoretical grid to the outskirts leads to a clear advantage in terms of rebalancing between the city and the territory and, therefore, can be considered highly efficient and valuable.

Now, outskirts are only a piece of the contemporary puzzle of settlement models, which is composed of:

- the old historical centres (involved in abandonment dynamics or touristical / business transformation or gentrification);

- the consolidated districts of the cities (built in the first half of the 20th century);

- $\quad$ the popular (legal and illegal) outskirts of the 50-80s;

- $\quad$ the suburbs (the dispersed, legal and illegal, city, from the 80 s to today).

The increase in per capita wealth implies a (globalized) tendency to live in larger (or more exclusive) spaces. The greater or lesser availability of financial resources is at the basis of the availability of space.

Wanting to summarize to the maximum, some social behaviours, which are consequently reflected on the settlement ones, can now be considered classic (and incredibly globalized):

- the wealthy classes always choose the best living contexts (for their needs and tastes): exclusive buildings in the centre or in large or very large suburban extensions;

- the middle classes aspire to imitate the behaviours of the rich and, how and when they can choose the context in which they live: condominiums in the centre or in small or very small suburban extensions;

- the poorer classes can never choose the context in which they live (but would like to do so) and set up where they can or where they are allowed to live.

However, any scenario must be based on an accurate knowledge of the territory and of the phenomena that affect it and on the indispensable participation (top down and bottom up) of the policies and therefore of the actions (plans, projects, programs) to be activated, based on a conscious sustainability.

\section{Bibliography}

ABRANTES, P.; ESTANQUEIRO, R., SIG, Análise Espacial e Ordenamento de Territórios Metropolitanos. In: Revista de Estudos Urbanos e Regionais, Sociedade e Território, № 41. Porto: Edições Afrontamento, 2008, pp. 114-124. ISSN: 0873-6380-41.

BAUMAN, Z., Modernità liquida. Roma-Bari, Laterza, 2002. ISBN 88-420-6514-5 
BERGOGLIO, J.M. (Franciscus PP.), Laudato Si'. Encyclical. Roma, 2015. http://w2.vatican.va/content/francesco/la/encyclicals/documents/papa-

francesco_20150524_enciclica-laudato-si.html

BLASCHKE, Thomas; MERSCHDORF, Helena, Geographic information science as a multidisciplinary and multiparadigmatic field. In: Cartography and Geographic Information Science, Vol. 41, N. 3, 2014, pp. 196-213, DOI: 10.1080/15230406.2014.905755

CECCHINI, A., Dieci considerazioni per il governo della città ovvero la questione delle periferie. In: $\mathrm{CECCHINI,} \mathrm{A.} \mathrm{(a} \mathrm{cura} \mathrm{di),} \mathrm{Al} \mathrm{centro} \mathrm{le} \mathrm{periferie.} \mathrm{II} \mathrm{ruolo} \mathrm{degli} \mathrm{spazi} \mathrm{pubblici} \mathrm{e} \mathrm{dell'attivazione}$ delle energie sociali in un'esperienza didattica per la riqualificazione urbana. Franco Angeli Editore. Milano, 2007.

CERASOLI, M., Cities of the world, a world of suburbs. Transformations of 'settlements rules' and 'forms of living' in contemporary Latin America (among globalization, cars and television). In: Czasopismo Techniczne. Architektura, Volume Y. 113, iss. 2-A, 2016, pp. 35-50.

CERASOLI, M., Periferias urbanas degradadas. Transformación de los espacios y evolución del habitar. ¿Cómo intervenir? In: ACE: Arquitectura, Ciudad y Entorno - Architecture, City and Environment, vol. 5, núm. 13, 2010, pp. 45-66.

EUROPEAN UNION, Mapping guide for European Urban Atlas. In: GMES, Observing our planet for a safer world, Regional Policy, 2011, 30p.

FABBRI, M., L'urbanistica italiana dal dopoguerra ad oggi. Storia, ideologie, immagini. Bari, De Donato Editore, 1983.

INSOLERA, I., Roma Moderna. Un secolo di storia urbanistica. 1870-1970. Torino, Einaudi, 1993.

LATOUCHE, S., La scommessa della decrescita. Milano, Feltrinelli, 2007. ISBN 978-88-07$17136-9$

MARTINELLI, F., Roma nuova. Borgate spontanee e insediamenti pubblici. Dalla marginalità alla domanda dei servizi. Milano, Franco Angeli, 1987.

RASHED, Tarek; JÜRGENS, Carsten (Eds.), Remote sensing for urban and suburban areas. In: Remote Sensing and Digital Image Processing, Vol. 10. London: Springer Science, 2010, 352p. ISBN 978-1-4020-4371-0, DOI 10.1007/978-1-4020-4385-7

RICCI, L. (eds.), I/ piano locale e.... Milano, Franco Angeli Editore, 2009, 384 p.

ROSSI, P.O., Roma. Guida all'architettura moderna 1909-1991. Roma-Bari, Editori Laterza, 1991, $392 \mathrm{p}$.

Citación: ESTANQUEIRO, R. y CERASOLI, M. Rome outskirts, Multidisciplinary survey on the transformation of settlement models. En: Libro de proceedings, CTV 2018. XII Congreso Internacional Ciudad y Territorio Virtual. Ciudades y Territorios Inteligentes. Mendoza, 5-7 septiembre 2018. Barcelona: CPSV, 2018, p. 97-114. 
TENEDÓRIO, J.A.; PONTES, S.; ESTANQUEIRO, R., V Capítulo - Uso do Solo: uma imagem do território metropolitano. In: Tenedório, J. A. (coord.), Atlas da Área Metropolitana de Lisboa. Lisboa: AML, 2003, ISBN: 972-98655-7-4. pp. 93-117.

VITTORINI, M., II Rinascimento della città. In: Quaderni del DPTU (Dipartimento di Pianificazione Territoriale e Urbanistica, Sapienza Università di Roma, 1988. 